\title{
Should we choose between problem-based learning and team-based learning? No, combine the best of both worlds!
}

Citation for published version (APA):

Dolmans, D., Michaelsen, L., Van Merrienboer, J., \& van der Vleuten, C. (2015). Should we choose between problem-based learning and team-based learning? No, combine the best of both worlds! Medical Teacher, 37(4), 354-359. https://doi.org/10.3109/0142159X.2014.948828

Document status and date:

Published: 01/04/2015

DOI:

10.3109/0142159X.2014.948828

Document Version:

Publisher's PDF, also known as Version of record

Document license:

Taverne

Please check the document version of this publication:

- A submitted manuscript is the version of the article upon submission and before peer-review. There can be important differences between the submitted version and the official published version of record.

People interested in the research are advised to contact the author for the final version of the publication, or visit the DOI to the publisher's website.

- The final author version and the galley proof are versions of the publication after peer review.

- The final published version features the final layout of the paper including the volume, issue and page numbers.

Link to publication

\footnotetext{
General rights rights.

- You may freely distribute the URL identifying the publication in the public portal. please follow below link for the End User Agreement:

www.umlib.nl/taverne-license

Take down policy

If you believe that this document breaches copyright please contact us at:

repository@maastrichtuniversity.nl

providing details and we will investigate your claim.
}

Copyright and moral rights for the publications made accessible in the public portal are retained by the authors and/or other copyright owners and it is a condition of accessing publications that users recognise and abide by the legal requirements associated with these

- Users may download and print one copy of any publication from the public portal for the purpose of private study or research.

- You may not further distribute the material or use it for any profit-making activity or commercial gain

If the publication is distributed under the terms of Article $25 \mathrm{fa}$ of the Dutch Copyright Act, indicated by the "Taverne" license above, 


\section{Should we choose between problem-based learning and team-based learning? No, combine the best of both worlds!}

\section{Diana Dolmans, Larry Michaelsen, Jeroen van Merriënboer \& Cees van der Vleuten}

To cite this article: Diana Dolmans, Larry Michaelsen, Jeroen van Merriënboer \& Cees van der Vleuten (2015) Should we choose between problem-based learning and teambased learning? No, combine the best of both worlds!, Medical Teacher, 37:4, 354-359, DOI: 10.3109/0142159X.2014.948828

To link to this article: https://doi.org/10.3109/0142159X.2014.948828

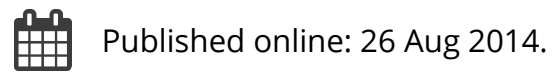

Submit your article to this journal

III Article views: 2785

Q View related articles ¿ك

View Crossmark data $[\pi$

Citing articles: 31 View citing articles 지 


\title{
Should we choose between problem-based learning and team-based learning? No, combine the best of both worlds!
}

\author{
DIANA DOLMANS ${ }^{1}$, LARRY MICHAELSEN ${ }^{2}$, JEROEN VAN MERRIËNBOER ${ }^{1}$ \& CEES VAN DER VLEUTEN ${ }^{1}$ \\ ${ }^{1}$ School of Health Professions Education (SHE), Maastricht University, The Netherlands, ${ }^{2}$ Department of Management, \\ University of Central Missouri, Warrensburg, USA
}

\begin{abstract}
Background: To meet changes in society and health care, medical curricula require continuous improvement. A relatively new development in medical education is team-based learning (TBL). In the previous century, problem-based learning (PBL) emerged as an exciting new method.

Aims: What are the similarities and differences between PBL and TBL? How do both approaches fit with current design principles? How might PBL and TBL benefit from each other's unique strengths?

Methods: Analysis of the literature.

Results: The overall similarities between PBL and TBL relate to the use of professionally relevant problems and small group learning, both fitting well with current instructional design principles. The main difference is that one teacher in TBL can run twenty or even more study teams, whereas in PBL each small group is run by one teacher.

Conclusion: In this paper we advocate for a joining of forces. By combining elements of PBL and TBL, we could create varied instructional approaches that are in keeping with current instructional design principles, thereby combining the best of both worlds to optimize student learning.
\end{abstract}

\section{Introduction}

Change being a stable characteristic of society and health care, continuing curriculum renewal is a familiar process in medical schools. In fact, medical schools all over the world regularly transform or modify their curricula to offer students optimal preparation for their work in the changing world of the health professions. Team-based learning (TBL) is presented as an attractive instructional approach especially for the acquisition of teamwork skills. Originating in business education in the 20th century, in the past decade TBL has made its entrance in health sciences education where its use is spreading rapidly Haidet et al. (2012).

Developed in medical education in the late 1960s, problembased learning (PBL) was heralded as an innovative educational approach and adopted by medical schools all over the world. As a student-centered as opposed to a teacher-centered approach, it was a major breakthrough in curriculum reform (Frenk et al. 2010), and many medical schools embraced it as an alternative to the then dominant discipline-based, teachercentered approach, characterized by content that was less relevant to practice, a strong emphasis on one directional transmission of knowledge and not enough emphasis on clinical reasoning and problem solving. PBL is used in many

\section{Practice points}

- Problem-based learning (PBL) and team-based learning (TBL) both use professionally relevant problems and small group learning and both fit well with current instructional design principles.

- $\quad$ PBL could benefit from structured peer feedback and inter-team discussions as is done in TBL.

- TBL could benefit from activating prior knowledge before pre-reading assignments and students generating questions or learning issues by themselves as is done in PBL.

schools today, and TBL is strongly advocated as an instructional approach that is eminently suitable to prepare students for effective collaboration (Frenk et al. 2010).

The co-existence of PBL and TBL in medical education raises several questions: What exactly are the differences and similarities? Is TBL the new breakthrough in education? What can we learn from these two instructional approaches? And, even more importantly: how do both approaches fit with current instructional design principles? Are there benefits to be gained from combining these approaches' unique strengths?

Correspondence: Diana HJM Dolmans, PhD, Department of Educational Development and Research, Faculty of Health, Medicine and Life Sciences, School of Health Professions Education, Maastricht University, FHML, PO Box 616, 6200 MD Maastricht, the Netherlands. Tel: 003143388 5730; E-mail: D.Dolmans@maastrichtuniversity.nl 
Instruction characteristic

Materials

Format

Teacher

Group activities and self-study

Group characteristics

Other curricular activities
PBL

Learning by addressing professionally relevant problems. All students work on the same problems.

Learning in small groups

One teacher facilitates each small group.

Students start with an initial discussion in the group to determine issues that need further self-study. All students study the same set of learning issues during individual self-study. Thereafter the group meets again to share and discuss findings.

Six to ten students per group. Students are randomly assigned to the groups. Group members stay together in a group for $6-10$ weeks and discuss several problems.

A limited number of supplementary lectures is included which take place after self-study and after the final discussion in the small group.
TBL

Learning by addressing professionally relevant problems. All students work on the same problems.

Learning in small teams

One teacher facilitates numerous small teams (20 or more).

Students start with mandatory pre-assigned reading during individual study. Students fill out a test (individually). Thereafter students discuss the exact same test items to reach team consensus and receive immediate feedback on their answers.

Five to seven students per team.

Students are purposefully assigned to the teams.

Group members stay together in a team for at least the duration of a course.

There are no traditional lectures. Students' initial exposure to the content is through pre-class study assignments and instructors' input is either corrective or confirmatory in nature and occurs: (1) at the conclusion of the team readiness tests and, (2) at the conclusion of the plenary class discussions in which teams have challenged each others' answers.
Since there are many variants of PBL and PBL is understood and practiced differently in many institutions (Taylor \& Miflin 2008), it seems logical to first describe our main characteristics before moving on to an examination of the possibilities for combining elements of PBL and TBL to maximize their joint educational powers (Table 1).

\section{The main characteristics of PBL}

PBL is a student-centered approach in which problems are the stimulus for learning. It is characterized by: (1) learning through problems, (2) small group sessions, (3) group learning facilitated by a teacher, and (4) learning through self-study (Barrows \& Tamblyn 1980; Barrows 1996; Hmelo-Silver 2004). The problems are professionally relevant and discussed in small groups in which all students work simultaneously on the same problem. One teacher facilitates each group. During the initial discussion of the problem in the group, students generate issues that need further self-study. All group members study the same set of learning issues during individual self-study. After self-study the group reconvenes to discuss the findings from self-study and synthesize what they have learnt. Students are randomly assigned to these groups (six to ten students per group) and usually stay together for a period of six to ten weeks during which they meet twice a week during two-hour sessions. After six to ten weeks the groups are reformed. A limited number of lectures are scheduled. These lectures are scheduled after individual self-study and after the final discussion in the group.

By discussing a pre-set problem students activate their prior knowledge, identify gaps in their knowledge vis-à-vis the problem and use these gaps to generate issues for self-study. During self-study students are exposed to new content and during the final discussion after self-study. During the final discussion, students listen and explain to other group members what they have learnt, discuss issues that were unclear or contradictory and apply their knowledge to the pre-set problem. The teacher plays an important role as facilitator by encouraging students to ask critical questions, engage in sound reasoning, constructively discuss cognitive disagreements, explain new knowledge in their own words and apply new knowledge and insights to solve the problem in question.

\section{The main characteristics of TBL}

TBL is a learner-centered, teacher-directed instructional approach for entire classes of students who are divided into small teams of between five and seven students to solve authentic problems (Michaelsen et al. 2008; Parmelee \& Michaelsen 2010; Parmelee et al. 2012). One teacher facilitates various small teams, 20 or even more. Before group sessions students have to complete a mandatory reading assignment and their individual knowledge of the materials is assessed in a multiple-choice test. In the teams, students discuss their individual answers to the exact same test items with each other to reach team consensus and receive immediate feedback on the team answers. Thereafter the teacher clarifies the concepts related to the test questions that students struggled with. Students then work in the same teams to resolve professionally relevant, challenging and complex problems and simultaneously reveal the solution or decision they have reached to the other teams in the class. The teacher facilitates the discussion in which the different teams challenge the decisions of other teams and defend their own decision in a plenary session. In TBL, the teams are self-managed but, the inter-team discussions are facilitated by one teacher. Within the teams, students exchange feedback on their performance in the group (Haidet et al. 2012). The main characteristics of TBL are: (1) professionally relevant problems, (2) small selfmanaged teams, (3) mandatory pre-class preparation by students, (4) an individual and a team test to determine students' readiness for dealing with complex decision-based professionally relevant problems, and (5) working on problems in teams (Parmelee et al. 2012). Peer evaluation and 


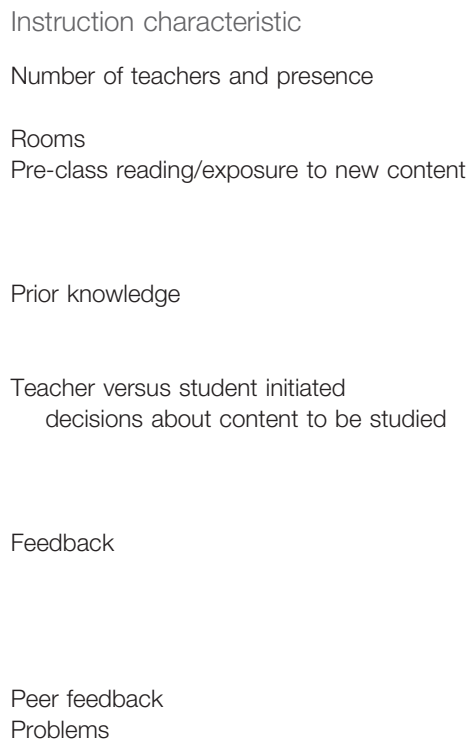

PBL

Many teachers; one per small group. Teacher physically present in each group. Groups work in different small rooms. No mandatory pre-class reading assignment before group discussion. Exposure to new content after initial group discussion during self-study and during final group discussion.

Students are not tested, but encouraged to activate their prior knowledge by means of an initial group discussion.

Students generate issues for self-study; students define what is not yet well understood after an initial group discussion of professionally relevant problem.

Feedback (both confirmatory and corrective) from peers during the final group discussion and if necessary from the teacher. No testing and no inter-group discussions.

No structured peer evaluations/feedback. Reasoning around problems with no specified questions.
$\mathrm{TBL}$

One teacher for many small teams. Teacher not physically present in each team.

Teams work in the same large room in teams.

Mandatory pre-class reading assignment before team discussion. Exposure to new content before the team discussion.

Students are tested individually and as a team to check their understanding of the reading assignments and prior knowledge.

Teacher defines content for pre-class study based on knowledge required for application problems that will be given during the unit. Teacher decides, on the basis of the group test, which issues are not yet well understood.

Feedback (both confirmatory and corrective) from peers and the teacher during team test, but also from interteam discussions after teams have revealed their choices, challenged others and attempted to defend their own.

Structured peer evaluations/feedback.

Reasoning around problems with associated questions. feedback is another important characteristic (Haidet et al. 2012). Students are purposefully assigned to teams using a stratified random sampling process.

\section{Similarities between PBL and TBL}

As learner-centered instructional approaches based on constructivist learning theory, PBL and TBL share two important characteristics: (1) learning around professionally relevant problems and (2) learning in small groups or teams. Both instructional approaches fit well with the first five principles of instruction of many current instructional approaches as defined by Merrill (2012): learning is promoted when (1) learners are engaged in whole or real-world problems; (2) existing knowledge is activated; (3) new learning is applied and (4) integrated or transferred. In both PBL and TBL students are encouraged during group work to apply their new knowledge to problems and to integrate or transfer their new knowledge by reporting it to peers in their own words. Furthermore, learning is promoted when (5) new knowledge is demonstrated to learners, e.g. by providing worked-out or modeling examples (Merrill, 2012). Although demonstration is not a primary instructional principle in PBL and TBL as opposed to many teacher-centered instructional approaches, demonstration, e.g. in terms of lectures, is not fully neglected in both curricula. So both PBL and TBL fit well with current first principles of instructional design as defined by Merrill (2012). Despite these similarities there are differences as well (Table 2).

\section{Differences between PBL and TBL}

A first major difference is that in TBL one teacher runs various groups simultaneously (even twenty teams or more with hundred students), while in PBL there is one teacher for 356 each group. So in PBL a teacher is physically present for each group discussion, whereas the teacher is not physically present for each team discussion. Students in PBL work in groups in different small rooms, whereas TBL teams work simultaneously in the same large room in small teams.

Another difference relates to the way students attain the knowledge and insight to address the problem they are working on. TBL students are given a mandatory pre-class reading assignment while PBL students are given no preparatory reading assignment. Exposure to new content in PBL takes place after initial group discussion, mainly during self-study but also during the final group discussion. Exposure to new content in TBL takes place before team discussion.

PBL students start with an initial discussion in which they activate their prior knowledge in the group. TBL students fill out a test individually and as a group to check whether they understand the pre-assigned reading materials; so prior knowledge is checked prior to the small group discussion.

Furthermore, where PBL students identify their own issues for self-study after the initial group discussion, in TBL it is the teacher who decides based on the nature of the application problems he or she will be requiring students to solve and the conclusion of the instructional units. Further, based on the test results, the instructor decides which issues need further explanation before students work in small teams to tackle the application problems.

Feedback (both confirmatory and corrective) to the students is given by peers within the group or team in both PBL and TBL. Furthermore, in both PBL and TBL the teacher gives corrective feedback to students when needed. However, in TBL students receive immediate feedback (confirmatory and corrective) from: (1) fellow team members while reaching consensus during the team discussion, (2) on the correctness of each team decision on the team test (via an scratch-off answer sheet), and (3) from members of other teams during 
inter-team discussions of the application problems. Testing and inter-group discussion are not part of regular PBL tutorials.

Peer evaluation and peer feedback are another difference between the approaches. Although peer feedback is also implemented in PBL in some schools, peer feedback is a structural component of TBL, with each team member having to give feedback to each of the other team members on their contributions to group learning. We will elaborate on this difference in the next section.

Learning in both PBL and TBL centers on reasoning around problems relevant to future professional practice. However, in TBL the mechanism through which the reasoning occurs is by requiring students to make questions and defend decisions to questions. TBL teams simultaneously reveal their answers in a plenary session and the teams discuss the decisions of the other teams and defend their own decision, facilitated by a teacher (Parmelee et al., 2012). Thus, students in TBL work on problems with associated questions, whereas students in PBL work on problems with no specified questions. Students in PBL discuss problems and generate their own issues or questions that need further self-study; so questions are not given.

In summary, the overall similarities between PBL and TBL relate to the use of professionally relevant problems and small group learning that both fit well with current instructional design principles, while the main difference relates to one teacher facilitating interactions between multiple self-managed teams in TBL, whereas each small group in PBL is facilitated by one teacher. Further differences are related to mandatory pre-reading assignments in TBL, testing of prior knowledge in TBL and activating prior knowledge in PBL, teacher-initiated clarifying of concepts that students struggled with in TBL versus students-generated issues that need further study in PBL, inter-team discussions in TBL and structured feedback and problems with related questions in TBL.

\section{Strengths of PBL and TBL}

PBL and TBL share various strong points. They both emphasize the importance of learning around professionally relevant problems in small groups. Both instructional approaches fit well with the five first principles of instruction of many current instructional approaches as defined by Merrill (2012) and explained above. The question is can PBL and TBL benefit from each other's unique strengths and, if the answer is affirmative, how do we achieve this?

\section{What do the two approaches have to offer each other?}

In addition to shared strengths, TBL and PBL have unique strengths. What can the two approaches offer each other or, to put it differently, how can PBL and TBL achieve mutual benefit by sharing strong points? How can the two approaches be combined?

\section{How can PBL profit from TBL?}

An important characteristic of TBL that might transfer to PBL is structured peer evaluation and feedback. In TBL, team members conduct mutual peer evaluation of their contributions to the success of the group and their own learning (Parmelee et al. 2012). Peer feedback has been shown to have positive effects on students' contributions to the team and on students' commitment to group work (Kamp et al. 2013). Also, it enhances awareness of desired behaviors in the group and positive social interdependence, and it increases intrinsic motivation, mutual support and collaboration among group members (Hattie \& Timperley 2007; Johnson et al. 2007). Borges et al. (2012) showed that, combined with peer feedback during a traditional clerkship, TBL enhanced students' awareness of their own emotions and recognition of the emotions of others, thereby promoting empathy. Peer feedback is also a helpful strategy for promoting individual member accountability. In short, peer feedback is a unique strength of TBL that could prove beneficial to PBL curricula in which peer feedback is not yet implemented as a routine and structured activity.

Another aspect of TBL that could be used in PBL is that the initial small group discussions could take place in a large class setting with one facilitator instead of a facilitator for each small group. The small groups discuss a professionally relevant problem and generate issues that need further self-study. The leader of each small group lists the learning issues generated and brings it to the teacher. Thereafter the teams report their learning issues in a plenary session. The teacher subsequently moderates a discussion in which teams challenge the choices of other teams and defend their own choices. In the end students have a list of learning issues for self-study. An advantage of this approach is that one teacher is needed for the discussion preceding the generation of learning issues. Another advantage is that the prior-knowledge base is expanded to an entire class consisting of several small teams and that inter-team discussions are facilitated.

\section{How can TBL profit from PBL?}

An important characteristic of PBL which may be of benefit to TBL is the small group discussion before self-study in which students activate their prior knowledge, a strategy that has been shown to have positive cognitive effects on learning (Dolmans \& Schmidt 2006; Van Blankenstein et al. 2011). In other words, although TBL does encourage the activation of prior knowledge by means of pre-reading assignments and does test students' prior knowledge by asking students to answer test items, either individually or in the team, TBL could benefit from encouraging students to activate their prior knowledge by actively contributing to the group discussion before pre-reading assignments.

Another characteristic of PBL that might be of benefit to TBL is encouragement of self-directed learning. In PBL, during small group discussions, students are encouraged to generate their own questions or learning issues for self-study, which they report on and discuss in the subsequent group discussion. In other words, students plan and monitor their own learning. Encouraging students to generate their own learning issues is 
PBL

$\mathrm{PBL}$ with structured peer feedback.

PBL with inter-team discussions in a large classroom during initial group discussions.
$\mathrm{TBL}$

TBL with group discussions before pre-reading assignments, to detect gaps in previously acquired knowledge.

$\mathrm{TBL}$ with generation of learning issues by students. assumed to have positive effects from a motivational perspective and on top of that may enhance the development of lifelong learning skills. So, TBL can encourage students to generate learning issues by themselves.

The proposed exchange of characteristics between PBL and TBL as discussed is summarized in Table 3.

\section{Conclusions and discussion}

Nowadays, TBL is implemented in many schools and advocated as an instructional method that offers students excellent preparation for professional practice. The above descriptions of PBL and TBL indicate that the two approaches share important similarities. Both instructional methods fit well with current first principles of curriculum design as defined by Merrill (2012) and both have unique strong points. We have tried to illustrate how the latter could offer opportunities for mutual benefit. By combining the strengths of the two approaches we might be able to optimize student learning in PBL and TBL, and perhaps create some hybrid approaches.

Some issues call for further discussion. Firstly, TBL is often claimed to be an economical or resource friendly instructional approach because one instructor can oversee the work of and ensure timely feedback to as many as twenty or more teams (Hrynchak \& Batty 2012; Parmelee et al. 2012). In times of resource shortages and increasing student numbers, this claim may have been instrumental in the breakthrough of TBL. PBL requires sufficient numbers of well-prepared tutors; one for each group which requires a lot of resources (Taylor \& Miflin 2008). But is TBL really less expensive than PBL? Further research will have to bring clarity on this issue.

A second discussion point is the transferability to PBL of the TBL characteristic of one teacher for many small groups. Can one teacher run various PBL groups simultaneously? In other words, can a group or team work well without a teacher? This would mean losing the advantage of having a teacher available to give just-in-time information or feedback during the group discussion. However, it may be worthwhile to consider the possibility of one teacher running groups simultaneously, once students have become familiar with the PBL approach; this would mean alternate group sessions with and without a teacher as described above. Further research will have to evaluate the impact of this way of reducing teacher support in PBL. Another way of cutting back on teacher support may be to employ student teachers. Although preferably practicing physicians are involved as teachers since they know what is relevant to learn (Dolmans et al. 2013), selected and motivated senior students trained to facilitate small groups can be as effective as teachers (De Rijdt et al. 2012). The question is whether senior students will be much cheaper than experienced teachers, in view of the considerable expenses for ongoing selection and training.

Thirdly, there is little clarity regarding the differential amounts of time devoted to lecturing, group discussion, selfstudy and other activities in PBL and TBL. Also, how much teacher support is given in PBL versus TBL? To what extent are students encouraged to self-direct their learning in PBL versus TBL? These issues deserve further exploration.

A fourth issue that needs further research is whether PBL and TBL differ in terms of problems that are used. Both approaches emphasize the importance of reasoning around problems. In TBL problems are associated with questions, in PBL there are no specified questions? But how do both approaches differ in terms of developing critical thinking and decision-making?

The fifth issue to be discussed is whether TBL will be the next breakthrough in health care education. Developing students' team work skills is crucial for the health care system and will become increasingly urgent as health care is facing an increase in problems of increasing complexity requiring multi-disciplinary team work. So the urgency of paying more attention to the development of teamwork skills in curricula and educational research is undeniable; both PBL and TBL can equip students with these skills.

Finally, we are faced with the choice between PBL and TBL. Which should we choose? Should we choose? In this paper, we have tried to argue that it is neither necessary nor desirable to make this choice. It may be more profitable to optimize student learning if we look for ways to combine the best of both worlds: PBL with structured peer feedback, PBL with study teams, TBL with initial group discussion before prereading assignment or testing or TBL with students generating their own learning issues. Choose an instructional approach that fits well with current design principles, such as the five first principles of Merrill (2012) emphasizing the importance of learning around problems, activation of prior knowledge, demonstration of new knowledge, and application and integration of knowledge. Ensure variability in problems to be discussed, order problems from simple to complex and gradually reduce teacher support (Van Merriënboer \& Kirschner 2013). Start with TBL, thereafter alternate TBL and PBL to decrease teacher support, and subsequently use PBL. Start with explanation problems and gradually add decision or strategic problems. Start with paper problems; thereafter use real patient problems so as to augment the fidelity of problems. There is a range of options to include real patient problems both in the pre-clinical and clinical phase (Harden et al. 2000; Diemers et al. 2008). Combine the strengths of PBL and TBL. In sum, think win-win when designing curricula in order to 
optimize student learning and use varied instructional approaches that fit well with current instructional design principles.

\section{Notes on contributors}

DIANA HJM DOLMANS, PhD, is Professor of Innovative Learning Arrangements, staff member of the School of Health Professions Education (SHE), Maastricht University, the Netherlands.

LARRY MICHAELSEN, PhD, is Professor of Management, creator of TeamBased Learning, and is a faculty member at the University of Central Missouri, USA.

JEROEN VAN MERRIËNBOER, PhD, is Professor of Learning and Instruction, Research Director of the School of Health Professions Education (SHE), Maastricht University, the Netherlands.

CEES VAN DER VLEUTEN, PhD, is Professor of Education, Chair of the Department of Educational Development and Research, scientific director of the School of Health Professions Education (SHE), Maastricht University, the Netherlands.

\section{Acknowledgements}

The authors thank Mereke Gorsira for her English editing of the text.

Declaration of interest: The authors report no conflicts of interest. The authors alone are responsible for the content and writing of this article.

\section{References}

Barrows HS. 1996. Problem-based learning in medicine and beyond A brief overview. In: Wilkerson L, Gijselaers WH, editors. New directions for teaching and learning. San Francisco: Jossey-Bass. pp $3-12$.

Barrows HS, Tamblyn RM. 1980. Problem-based learning. An approach to medical education. New York: Springer.

Borges NJ, Kirkham K, Deardorff AS, Moore JA. 2012. Development of emotional intelligence in a team-based internal medicine clerkship. Med Teach 34:802-806

De Rijdt C, van der Rijt J, Dochy F, van der Vleuten C. 2012. Rigorously selected and well trained senior student tutors in problem based learning: Student perceptions and study achievements. Instructional Sci 40:397-411.
Diemers AD, Dolmans DH, Verwijnen MG, Heineman E, Scherpbier AJ. 2008. Students' opinions about the effects of preclinical patient contacts on their learning. Adv Health Sci Educ 13(5):633-647.

Dolmans D, Schmidt HG. 2006. What do we know about cognitive and motivational effects of small group tutorials in problem-based learning? Adv Health Sci Educ 11:321-336.

Dolmans DH, Wolfhagen IH, Van Merriënboer JJ. 2013. Twelve tips for implementing whole-task curricula: How to make it work. Med Teach 35(10):801-805.

Frenk J, Chen L, Bhutta ZA, Crisp N, Evans T, Fineberg T, Garcia P, Ke Y, Kelley P, Kistnasamy B, et al. 2010. Health professionals for a new century: transforming education to strengthen health systems in an interdependent world. The Lancet 376:1923-1957.

Haidet P, Levine RE, Parmelee DX, Crow S, Kennedy F, Kelly A, Perkowski L, Michaelsen L, Richards BF. 2012. Guidelines for reporting team-based learning activities in the medical and health sciences education literature. Acad Med 87(3):292-299.

Harden RM, Crosby J, Davis MH, Howie PW, Struthers AD. 2000. Taskbased learning: the answer to integration and problem-based learning in the clinical years. Med Educ 34(5):391-397.

Hattie J, Timperley H. 2007. The power of feedback. Rev Educ Res 77: 81-112.

Hmelo-Silver CE. 2004. Problem-based learning: What and how do students learn? Educ Psychol Rev 16(3):235-266.

Hrynchak P, Batty H. 2012. The educational theory basis of team-based learning. Med Teach 34:796-801.

Johnson DW, Johnson RT, Smith K. 2007. The state of cooperative learning in postsecondary and professional settings. Educ Psychol Rev 19:15-29.

Kamp RJA, Dolmans DHJM, Van Berkel H, Schmidt HG. 2013. The effect of midterm peer feedback on student functioning in problem-based tutorials. Adv Health Sci Educ 18:199-213.

Merrill MD. 2012. First principles of instruction. San Francisco, CA: John Wiley and Sons.

Michaelsen LK, Parmelee DX, McMahon KK. 2008. Team-based learning for health professions education: A guide to using small groups for improving learning. Sterling, VA: Stylus Publishing, LLC.

Parmelee DX, Michaelsen LK. 2010. Twelve tips for doing effective TeamBased Learning (TBL). Med Teach 32(2):118-122.

Parmelee D, Michaelsen LK, Cook S, Hudes PD. 2012. Team-based learning: A practical guide: AMEE Guide No. 65. Med Teach 34: e275-e287.

Taylor D, Miflin B. 2008. Problem-based learning: Where are we now? Med Teach 30(8):742-763.

Van Blankenstein FM, Dolmans DHJM, Vleuten van der CPM, Schmidt HG. 2011. Which cognitive processes support learning during small-group discussion? The role of providing explanations and listening to others. Instr Sci 39:189-204.

Van Merriënboer JJG, Kirschner PA. 2013. Ten steps to complex learning (2nd Rev. Ed.). New York: Routledge. 